\title{
Profile of Nursing research groups of the National Council for Scientific and Technological Development
}

\author{
Perfil dos grupos de pesquisa de Enfermagem do Conselho Nacional de Desenvolvimento \\ Científico e Tecnológico
}

\author{
Perfil de los grupos de investigación en Enfermería del Consejo Nacional de Desarrollo \\ Científico y Tecnológico
}

Andréia Cristina Barbosa Costa $^{1}$, Erika de Cássia Lopes Chaves $^{2}$, Fábio de Souza Terra ${ }^{2}$, Lidiane Aparecida Monteiro $^{2}$

Nursing has been developing in the research field, therefore, it is important to be inserted into a research group of the National Council for Scientific and Technological Development, a funding agency that supports studies and strengthens the knowledge. This is a descriptive, retrospective and cross-sectional study that aimed to investigate the profile of Nursing research groups registered in the National Council for Scientific and Technological Development. A survey of data from research groups in Nursing took place in the first half of 2012, finding 440 groups. The Southeast region was the one that presented more research groups registered (49.5\%). The leaders of the groups had from one to ten productions with Impact Factor (49.1\%). It is concluded that Nursing is expanding in the research field, and that many Brazilian regions need to be encouraged, as this is a form of developing the area.

Descriptors: Nursing; Governmental Research Institutes; Directories of Research Institutions; Nursing Research.

A Enfermagem tem se desenvolvido no campo da pesquisa, por isso é importante que esteja inserida em um grupo de pesquisa do Conselho Nacional de Desenvolvimento Científico e Tecnológico, agência de fomento que apoia os estudos, fortalecendo o saber. Trata-se de um estudo descritivo, retrospectivo e transversal, que objetivou investigar o perfil dos grupos de pesquisa em Enfermagem cadastrados no Conselho Nacional de Desenvolvimento Científico e Tecnológico. No primeiro semestre de 2012, foi realizado um levantamento de dados dos grupos de pesquisa em Enfermagem, sendo encontrados 440 grupos. A região que mais possuía grupos de pesquisa cadastrados foi a Sudeste do Brasil (49,5\%). Os líderes dos grupos possuíam entre uma e dez produções com Fator de Impacto (49,1\%). Conclui-se que a Enfermagem está se expandindo no campo da pesquisa e que muitas regiões brasileiras precisam ser incentivadas, já que esta é uma forma de desenvolvimento da área.

Descritores: Enfermagem; Institutos Governamentais de Pesquisa; Diretórios de Instituições de Pesquisa; Pesquisa em Enfermagem.

La enfermería se ha desarrollado en el campo de la investigación, así es importante que se inserte en un grupo de investigación del Consejo Nacional de Desarrollo Científico y Tecnológico, agencia de desarrollo que apoya los estudios, fortaleciendo lo saber. Estudio descriptivo, retrospectivo y transversal, cuyo objetivo fue investigar el perfil de los grupos de investigación en enfermería registrados en Consejo Nacional de Desarrollo Científico y Tecnológico. En el primer semestre de 2012, se realizó levantamiento de datos de los grupos de investigación en enfermería, y 440 grupos fueron encontrados. La región que más tenía grupos de investigación registrados fue la Sureste del Brasil (el 49,5\%). Los líderes de los grupos tenían entre una y diez producciones con Factor de Impacto (49,1\%). La enfermería está expandiéndose en el campo de la investigación, y que muchas regiones brasileñas deben ser alentadas, ya que esta es una forma de desarrollo del área.

Descriptores: Enfermería; Institutos Gubernamentales de Investigación; Directorios de Instituciones de Investigación; Investigación en Enfermería.

\footnotetext{
${ }^{1}$ Escola de Enfermagem de Ribeirão Preto, Universidade de São Paulo. Alfenas, MG, Brazil.

${ }^{2}$ Universidade Federal de Alfenas. Alfenas, MG, Brazil.

Corresponding author: Erika de Cássia Lopes Chaves

Av. Afonso Pena, 898. Centro. CEP: 37.130.000. Alfenas, MG, Brazil. E-mail: echaves@usp.br
} 


\section{Introduction}

Over the years, Nursing professionals have rethought their ways of doing, researching and educating, thus reflecting the desire to advance and enhance the professional development ${ }^{(1)}$. In this scenario, arises the need to implement the research field to absorb, produce, refine and reproduce knowledge in order to improve the quality of life in general, the scientific development and the technical enhancement $^{(2)}$.

Nevertheless, the field of science in Brazil began its enrichment with the creation of the National Research Council, ruled by Law 1,310/51, enacted on January 15, 1951, aiming to promote and stimulate the development of scientific and technological research by providing resources for research and the training of researchers and technicians in the several fields of knowledge ${ }^{(3)}$. Therefore, the National Research Council intended to support science, technology and innovation in the formation and incorporation of human resources, besides funding research projects that contribute in increasing the knowledge production $^{(4)}$.

In this way, exploring research represented an important strategy for social development, coordinating public and institutional policies with funds that maintained and strengthened the studies developed by Nursing researchers. In this perspective, the National Research Council improved the policy for scientific and technological development and innovation in the country with significant progress in the area of Nursing ${ }^{(5)}$. This progress has generated a greater demand for financial resources, increasing requests for funding by the Coordination for the Improvement of Higher Education Personnel and other agencies, aimed at stimulating the formation of high-level human resources and standards of excellence ${ }^{(6)}$.

Another achievement to consolidate science was the approval of the Graduate Education by the
Federal Council of Education in mid-1965, and its expansion in the 1980s, since it was indispensable to form teachers able to meet the needs of universities, to work and stimulate the development of research with significant scientific production in the area of Nursing. In this context, new researchers have emerged, developing theses, dissertations, books and scientific articles, increasingly innovating care techniques ${ }^{(7-8)}$.

In the 1970s, there was an encouragement movement to intellectual activity in graduate programs, culminating in changing the name of the National Research Council to National Council for Scientific and Technological Development. In this scenario, it also appeared the first Nursing research group in Brazil. These groups are forms of organization appropriate for performing shared or collective activities for the production of knowledge with control standards, serving as an instrument for promoting and providing opportunities for advancement in production. Furthermore, it provides the interaction between people, allowing the expansion of the solutions of complex problems, which do not always rely on results from a single specialty of knowledge ${ }^{(5)}$.

The research groups are allocated within the research directory, which corresponds to the database that contains information about these active groups in the country, being an effective instrument for the exchange of information ${ }^{(4)}$.

The development of studies that describe the profile of research groups is essential to demonstrate its structure in the area of Nursing, its potentials, limitations and weaknesses, indispensable to outline strategies for strengthening Brazilian research groups, since they are extremely important for the development of Nursing as a profession and a science. In this context, the present study aimed to investigate the profile of research groups in the field of Nursing registered in the directory of the National Council for Scientific and Technological Development and associate it with their scientific production. 


\section{Method}

This is an analytical descriptive, cross-sectional, retrospective study conducted through a survey of data from Nursing research groups registered in the Research Group Directory of the National Council for Scientific and Technological Development by using the keyword "Nursing" and selecting the filter "area of Nursing". All groups registered through June 2012 were considered, totaling 440 groups.

The study occurred in the first half of 2012 . For data collection, the researchers constructed an instrument that included the following variables: formation year of the group, update year of the group, area of interest, region, institution, number of researchers and students, lines of research, profile of the leader and students, production of leaders with Impact Factor, and whether they had a scholarship granted by the National Council for Scientific and Technological Development, the purpose of the groups, as well as whether they received some funding.

Data were organized through Microsoft Word and Excel programs, and statistically analyzed using the Statistical Package for the Social Sciences, version 17, applying Pearson's chi-squared test to analyze the association between variables. It was considered a significance level of $5 \%(p<0.05)$.

\section{Results}

The study investigated 440 research groups registered in the area of Nursing in the Research Group Directory of the National Council for Scientific and Technological Development, belonging to several public $(89.8 \%)$ and private $(10.2 \%)$ institutions of Higher Education, of which $49.5 \%$ were in the Southeast Region of Brazil, followed by the South (21.4\%) and Northeast (20\%).

As for the year of formation of research groups investigated, it can be observed that, in 2012, most had been created over 5 years (53.4\%) and 49.1\% were updated in the directory.
The groups stood out in the category called Other subareas (35.7\%), which means they did not specify their subareas or fitted into more than one. Subsequently, there was predominance of the MedicalSurgical subarea (20.0\%), followed by Public Health (18.4\%), according to Table 1.

Table 1 - Subarea of expertise of the Nursing research groups registered in the National Council for Scientific and Technological Development.

\begin{tabular}{lc}
\hline Subarea & n (\%) \\
\hline Medical-Surgical & $90(20.0)$ \\
Public Health & $81(18.4)$ \\
Management & $43(9.7)$ \\
Child Health & $22(5.0)$ \\
Mental Health & $22(5.0)$ \\
Women's Health & $15(3.4)$ \\
Maternal and Infant Health & $12(2.7)$ \\
Others & $155(35.7)$ \\
\hline
\end{tabular}

It was observed the predominance of lines of research related to Nursing Care/Specialties (55.4\%) (Table 2). Nursing Care/Specialties means that the groups focused on the lines of Nursing care in general or specifically in some area, such as in oncology, pediatrics, among others. It is worth mentioning that the leaders of the research groups chose the lines of research, they are not an option offered by the National Council for Scientific and Technological Development.

Table 2 - Lines of research of Nursing groups registered in the National Council for Scientific and Technological Development

\begin{tabular}{lc}
\hline Lines of research* & n (\%) \\
\hline Nursing Care/Specialties & $244(55.4)$ \\
Communication and Education & $130(29.5)$ \\
Nursing Administration/Management & $81(18.4)$ \\
Promotion and Prevention & $66(15.0)$ \\
Treatment & $33(7.5)$ \\
Health Policies and Practices & $24(5.4)$ \\
Society/Worker's Health & $13(2.9)$ \\
Epidemiology & $13(2.9)$ \\
Palliative Care & $10(2.2)$ \\
Others & $27(6.1)$ \\
\hline *There was more than one answer
\end{tabular}

*There was more than one answer 
When investigating the objectives of the research groups, it was noted that the groups aimed at promotion and prevention (20.9\%), care (20.2\%), teaching and research (19.3\%), education and guidance $(15.2 \%)$, the quality of care $(11.4 \%)$, management (8.6\%), and treatment (3.2\%). Nonetheless, there were some groups that did not identify their purposes (1.2\%).

As expected, when researching the highest degree of the leaders of the research groups, there was a predominance of doctor's degree $(91.3 \%)$, followed by master's ( $8.1 \%)$ and specialization $(0.4 \%)$.

After evaluating 5,433 members distributed in the research groups, it was verified that most of them had completed or ongoing undergraduate (45.3\%), followed by master's (25.6\%) and doctorate (15.0\%). It is worth highlighting there was more than one answer and there were groups that included school students and professional technicians (Table 3).

Table 3 - Profile of members of the Nursing research groups registered in the National Council for Scientific and Technological Development

\begin{tabular}{lc}
\hline Profile of members* & n (\%) \\
\hline Undergraduate & $2.463(45.3)$ \\
Master's & $1.394(25.6)$ \\
Doctorate & $816(15.0)$ \\
Specialization students & $632(11.6)$ \\
High school & $92(1.7)$ \\
Professional technician & $14(0.2)$ \\
Post-doctorate & $4(0.1)$ \\
Unidentified & $18(0.3)$ \\
\hline${ }^{*}$ There was more than one answer
\end{tabular}

By reviewing the scientific production, especially the leaders of the research groups, considering the Impact Factor, in accordance with the Journal Citation Reports, it was noted that $49.1 \%$ had from one to ten productions with Impact Factor and that $21.4 \%$ had none (Table 4). However, only $23.6 \%$ of the leaders of the research groups had grants funded by the National Council for Scientific and Technological Development.
Table 4 - Production with Impact Factor of the leaders of the Nursing groups registered in the National Council for Scientific and Technological Development

\begin{tabular}{lc}
\hline Number of productions with Impact Factor & n (\%) \\
\hline $1-10$ & $216(49.1)$ \\
$11-20$ & $60(13.6)$ \\
$21-30$ & $19(4.3)$ \\
$31-40$ & $21(4.8)$ \\
$41-50$ & $18(4.1)$ \\
$51-100$ & $11(2.5)$ \\
$>100$ & $1(0.2)$ \\
None & $94(21.4)$ \\
\hline
\end{tabular}

Regarding the research groups funded by financing agencies, it was noticed that $42 \%$ did not receive any funding for the research development, and $32 \%$ had more than one financing institution, since they were funded, for example, by agencies such as the National Council for Scientific and Technological Development and the Coordination for the Improvement of Higher Education Personnel at the same time (Table 5).

Table 5 - Nursing research groups registered in the National Council for Scientific and Technological Development funded by financing agencies

\begin{tabular}{lc}
\hline Financing agencies & n (\%) \\
\hline More than one financing agency & $141(32.0)$ \\
National Council for Scientific and Technological & $40(9.1)$ \\
Development & \\
Coordination for the Improvement of Higher & $37(8.5)$ \\
Education Personnel & $18(4.1)$ \\
Others & $17(3.9)$ \\
State Foundations for Research Support & $1(0.2)$ \\
The very Educational Institution & $1(0.2)$ \\
International Institution & $185(42.0)$ \\
\hline
\end{tabular}

By associating the variables lines of research with the subareas of activity of Nursing research groups registered in the National Council for Scientific and Technological Development, it was found a statistically significant association between these variables $(\mathrm{p}=0.000)$, since in the subareas of Public Health and Medical-Surgical they focused on the line of Nursing Care in Specialties; the Promotion/Prevention line 
stood out only in the Subarea of Public Health. As for the Education line, it predominated in the subareas of Child Health and Public Health Management.

With regard to the association between the variables lines of research and production of the leaders of the Nursing research groups registered in the National Council for Scientific and Technological Development, we identified that there was no statistical association $(\mathrm{p}=0.764)$ between these variables. The same could be observed by associating the variables areas of expertise with the production of the leaders of the research groups $(\mathrm{p}=0.391)$.

There was statistical association between the variables of production of leaders with their academic title $(\mathrm{p}=0.000)$, since the higher the degree, the higher the number of productions with Impact Factor, in other words, doctors produced more than masters.

As regards the variable production of leaders associated with the variable leaders that received financial support, it was found a statistically significant association between them $(p=0.000)$, since the leaders that received financial support presented higher production with impact factor in relation to those who did not, as expected.

By associating the variables production of leaders with years of formation of research groups, it was found that there was statistically significant association ( $\mathrm{p}=0.034)$, since the leaders of the groups created for 5 years or more had a greater number of production with impact factor when compared to leaders of groups formed in recent years.

Public institutions have a much higher number of productions than private institutions, with a notable statistical difference when associating the variables production of leaders with the institutions $(\mathrm{p}=0.006)$.

\section{Discussion}

In Brazil, there has been a development of Nursing in the research field, with notable growth of research groups in the area, increased production and qualification of members ${ }^{(5)}$. This fact can be evidenced by information derived from the study that affirms that there were approximately 270 Nursing groups registered in the Research Group Directory of the National Council for Scientific and Technological Development in $2008^{(7)}$ and, until the date of this research, this number had already reached 440 groups - reminding that this may vary according to date of collection.

The increase of research groups in recent years is noticeable. This is due to the growth of graduate programs ${ }^{(5)}$, as well as the obligation of researchers that use the National Council for Scientific and Technological Development to register a Curriculum Lattes, strengthening the bond between institutions and this organ, which led to a greater demand on researchers for the formation and registration of their groups in the Research Group Directory of the National Council for Scientific and Technological Development ${ }^{(9)}$.

It is essential to highlight that Nursing research groups from public institutions stood out compared to those registered in private institutions. Based on this, we can assume that there is a gap in the research development in private institutions, since the curriculum guidelines focus on teaching, research, and extension ${ }^{(10)}$.

The fact that most research groups registered in the National Council for Scientific and Technological Development come from public institutions of Higher Education $^{(3)}$ occurs because the public university is a privileged space of production and scientific socialization, considered the center of knowledge production in Nursing. The works produced by public universities represent the majority of total production in the country. This is due to the support of federal agencies in research funding ${ }^{(11)}$.

Most Nursing research groups registered in the National Council for Scientific and Technological Development are located in the Southeast Region of Brazil, followed by the South, Northeast, Midwest and North. These data reflect both the onset of the Graduate Program in Nursing, as the concentration of 
larger number of Graduate Programs in Nursing in the Southeast and South Regions, respectively ${ }^{(9)}$.

The formation of such research groups began in 1982, gradually and slowly, but it has increased significantly in recent years. Alongside this fact, there was an elevated number of productions ${ }^{(9)}$. Besides the growing number of groups and the amount of production, it is also important that they have quality. For this purpose, there is need for more investment in the academic infrastructure, which should increase the dissemination of knowledge in order to improve research in Nursing, both at national and international levels ${ }^{(10)}$.

In the present study, it can be verified that $49.1 \%$ of Nursing research groups registered in the National Council for Scientific and Technological Development were updated in 2012 - which is a requirement, since, according to the guidelines of the Research Group Directory of the National Council for Scientific and Technological Development, the group must be updated every 12 months from its creation. If that does not happen, it goes to the status of "nonupdated group," which may return to the status of certified group as soon as they are updated. After 12 months without update, the group may be excluded from the database of the National Council for Scientific and Technological Development ${ }^{(12)}$.

It is also noticed that most groups approach more than one subarea. Thus, the division of groups by subareas of activity is a form of organization by themes, disciplines, fields of knowledge and expertise, among others, all associated with the lines of research that direct studies to produce the same conceptual framework $^{(5)}$.

The proximity of the researcher in the same subarea with an educational institution facilitates the production process, since there are common interests among group members in producing on the same line of research ${ }^{(10)}$.

According to the literature, the subareas of publication of greatest interest are health education and Nursing, followed by adult and elderly health, public health and home health. This is justified by the fact that most journals are from undergraduate and graduate courses, and because there are many groups covering these areas ${ }^{(13)}$.

It is verified that most groups have their purposes focused on education. This probably occurs because education and teaching in Nursing directly influence care, as they improve the quality of services, and develop solidarity and individual and collective responsibility, thus contributing to the inclusion of reflective practitioners into the labor market ${ }^{(14)}$.

According to data of this study, the highest degree of the leaders of the Nursing research groups was the $\mathrm{PhD}$. It is worth mentioning that the participation of doctors in developing research is fundamental, besides reflecting the investments of graduate Nursing programs ${ }^{(15)}$.

Regarding the profile of the members of the research groups, it was identified the participation of 5,433 people, with $45.3 \%$ undergraduate students, $25.6 \%$ master's students, and $15.0 \%$ doctoral students, revealing a significant participation of students interested in scientific initiation and research. This growth is consistent with the increase in postgraduate courses, which encourage and direct the production of knowledge $\mathrm{e}^{(9)}$.

During the study, it was also identified a significant number of research groups without registered students, which should be avoided, since it may hinder the training of students. Their participation in research groups should be encouraged from the start of undergraduate, since it is possible to notice that the interest arises even before entering Higher Education - as noted by the small share of high school students ${ }^{(15)}$.

The knowledge production activities have been developed by researchers who meet in research groups registered in the Research Group Directory of the National Council for Scientific and Technological Development. Among these researchers, 64\% were doctors, which leads to observe their participation in the development of research in Nursing and reflects 
the investment of postgraduate programs ${ }^{(9)}$. Most research works in Nursing are focused on academics, universities and graduate programs ${ }^{(13)}$.

Regarding the production of the leaders, $49.10 \%$ had from one to ten productions with Impact Factor, and $21.4 \%$ had no production fitting this category. The Impact Factor began to be considered as an instrument for evaluating scientific journals from the 1960s, as a means to classify and evaluate them. The journal's prestige is related to the critical process of peer review, the quality of published articles and the visibility of publication, that occur through the indexes in the databases and the Impact Factor ${ }^{(16)}$. It is worth highlighting that the only Brazilian journals of Nursing that have Impact Factor are the Journal of São Paulo University School of Nursing (JCR=0.387) and the Latin American Journal of Nursing (JCR=0.540).

Among the leaders of the Nursing research groups, only $23.6 \%$ had scholarship granted by the National Council for Scientific and Technological Development. It is worth noting that the scholarship for research productivity from the National Council for Scientific and Technological Development is conceived as a way of encouraging $\mathrm{PhD}$ researchers who stand out in the scientific production in order to value their work and dedication ${ }^{(17) .}$

Regarding the funding of Nursing research groups registered in the National Council for Scientific and Technological Development, it is observed that $42 \%$ did not have any funding for the research development and 32\% had more than one funding institution. Study points out the main national research funding agencies, highlighting the participation of the National Council for Scientific and Technological Development, the Coordination for the Improvement of Higher Education Personnel and the State Foundations for Research Support ${ }^{(18)}$. The National Council for Scientific and Technological Development is an important fostering agency that has, over the years, supporting and outlining trends and studies that strengthen multidisciplinarity and the theoretical and methodological pluralism for the construction of knowledge ${ }^{(19)}$. The financial incentive from national funding agencies contribute to the improvement of research in Brazil, being crucial to the survival of the research groups ${ }^{(20)}$.

The purpose of a scientific work is achieved through its publication, and developing a research requires financing. It is worth mentioning that, for enhancing research funding, it is necessary to demonstrate productivity, mainly through academic publications, which originates competitiveness between articles and journals that seek to occupy the best editorial spaces ${ }^{(18)}$.

In this study, it was noted that the academic title had no association with the existence of financial aid. In contrast to these findings, study emphasized that, when selecting candidates for the scholarship, the National Council for Scientific and Technological Development does not evaluate the student, rather the supervisor-researcher responsible for the project, considering adequate for this activity the researchers with higher academic titles and production ${ }^{(2)}$.

When associating the variables region and academic title, it was not identified statistically significant association. What can be observed is that doctors are more concentrated in the South and Southeast Regions of Brazil - which can be explained by the higher concentration of research groups in universities located in the Southeast, especially in the city of São Paulo ${ }^{(9)}$.

Although in development, research in the area of Nursing still requires strategies that ensure working conditions for researchers in their own institutions, advancing in knowledge production ${ }^{(5)}$, and thus promoting the development of research in Nursing, besides expanding the quality at this level of teaching ${ }^{(15)}$.

\section{Conclusion}

Nursing is expanding in the scientific field, and many Brazilian regions need more incentives and financing to enhance the research development. It is 
noteworthy that the leaders of the Nursing research groups registered in the National Council for Scientific and Technological Development, through funding, can foster productions with Impact Factor, which makes them much more significant, with better visibility and acceptability in the scientific community.

There is a greater interest of students in participating in research groups, which should be even more encouraged, so that the area of Nursing no longer operates empirically and increasingly become an evidence-based profession.

The increase in graduate Nursing courses has also contributed to the development of research at the national level, providing the update and the qualification, which is paramount to rescue the recognition of Nursing professionals.

\section{Collaborations}

Costa ACB contributed to the conception of the study, analysis, data collection, data interpretation, and drafting of the article. Chaves ECL and Terra FS contributed to the conception of the study, analysis, data interpretation, and final approval of the version to be published. Monteiro LA contributed to the conception of the study, analysis, data collection, data interpretation, and drafting of the article.

\section{References}

1. Lino MM, Backes VMS, Ferraz F, Reibnitz KS, Martini JG. Pedagogical position adopted in nursing and health education in the Brazilian South Region. Rev Bras Enferm. 2011; 64(1):1529.

2. Erdmann AL, Leite JL, Nascimento KC, Lanzoni GMM. Glimpsing undergaduate research from the view of the advisors of Nursing scholarships. Rev Bras Enferm. 2011; 64(2):261-7.

3. Backes VMS, Prado ML, Lino MM, Ferraz F, Reibnitz KS, Canever BP. Nursing Education Research Groups in Brazil. Rev Esc Enferm USP. 2012; 46(2):436-42.
4. Conselho Nacional de Desenvolvimento Científico e Tecnológico (CNPq). 0 CNPq [Internet]. [citado 2014 jun. 7]. Disponível em: http://www.cnpq. $\mathrm{br} /$ web/guest/o-cnpq;jsessionid=3ABEBC3E0AA CA3F09D8540F4BFA85281

5. Erdmann AL, Lanzoni GMM. Research group characteristics of the Brazilian Nursing certificated by the CNPq from 2005 to 2007. Esc Anna Nery. 2008; 12(2):316-22.

6. Pepe VLE, Noronha ABM, Figueiredo TA, Souza AAL, Oliveira CVS, Pontes Júnior DM. A produção científica e grupos de pesquisa sobre vigilância sanitária no CNPq. Ciênc Saúde Coletiva. 2010; 15(supl. 3):3341-50.

7. Lima CKG, Sanna MC. Scientific production trajectory of the São Paulo Federal University Post-Graduate Program in Nursing Services Management. Rev Bras Enferm. 2008; 61(3):3259.

8. Padilha MI, Borenstein MS, Carvalho MAL, Ferreira AC. Nursing history research groups: a Brazilian reality. Rev Esc Enferm USP. 2012; 46(1):192-9.

9. Barbosa SFF, Dal Sasso GTM, Berns I. Nursing and technology: analysis of the research groups registered in the CNPq Lattes Platform. Texto Contexto Enferm. 2009; 18(3):443-8.

10. Backes VMS, Canever BP, Ferraz F, Lino MM, Prado ML, Reibnitz KS. Grupos de pesquisa de educação em enfermagem da região sul do Brasil. Rev Gaúcha Enferm. 2009; 30(2):249-56.

11. Silva RB, Dagnino R. Universidades públicas brasileiras produzem mais patentes que empresas: isso deve ser comemorado? Rev Econ Tecnol. 2009; 17:115-8.

12. Conselho Nacional de Desenvolvimento Científico e Tecnológico (CNPq). Grupos de pesquisa: saiba mais [Internet]. [citado 2014 jun. 7]. Disponível em: http://dgp.cnpq.br/diretorioc/html/faq.html

13. Dyniewicz AM. Analysis of clinical nurses' publications in national jornal. Rev Bras Enferm. 2010; 63(6):1046-51.

14. Lino MM, Backes VMS, Ferraz F, Reibnitz KS, Martini JG. Scientific production analysis of nursing education research groups in Southern Brazil. Texto Contexto Enferm. 2010; 19(2):26573. 
15. Munari DB, Chaves LDP, Peduzzi M, Laus AM, Fugulin FMT, Ribeiro LCM, et al. The setting of research production by nursing and management graduate programs in Brazil. Rev Esc Enferm USP. 2011; 45(n. spe):1543-50.

16. Ruiz MA, Greco OT, Braile DM. Fator de impacto: Importância e influência no meio editorial, acadêmico e científico. Rev Bras Cir Cardiovasc. 2009; 24(3):273-8.

17. Santos NCF, Cândido LFO, Kuppens CL. Produtividade em pesquisa do CNPq: análise do perfil dos pesquisadores da química. Quim Nova. 2010; 33(2):489-95.
18. Aquino SN, Martelli DRB, Bonan PRF, Laranjeira AL, Martelli Júnior H. Produção científica odontológica e relação com agências de financiamento de pesquisa. Arq Odontol. 2009; 45(3):142-6.

19. Salles EB, Barreira IA. The development of nursing scientific community in Brasil. Texto Contexto Enferm. 2010; 19(1):137-46.

20. Erdmann AL, Mello ALF, Andrade SR, Klock P. Funcionalidade dos grupos de pesquisa de administração/gestão/gerência de enfermagem. Rev Rene. 2010; 11(2):19-26. 